\title{
Prevalence and risk factors of some arthropod-transmitted diseases in cattle and sheep in Jordan
}

\author{
Zaidoun S. Hijazeen, Zuhair Bani Ismail and Ahmad M. Al-Majali
}

\author{
Department of Veterinary Clinical Sciences, Faculty of Veterinary Medicine, Jordan University of Science and Technology, \\ Irbid 22110, Jordan. \\ Corresponding author: Zuhair Bani Ismail, e-mail: zuhair72@just.edu.jo \\ Co-authors: ZSH: kalanzi80@yaho.com, AMA: almajali@just.edu.jo \\ Received: 27-09-2019, Accepted: 26-12-2019, Published online: 28-01-2020
}

doi: www.doi.org/10.14202/vetworld.2020.201-205 How to cite this article: Hijazeen ZS, Ismail ZB, Al-Majali AM (2020) Prevalence and risk factors of some arthropod-transmitted diseases in cattle and sheep in Jordan, Veterinary World, 13(1): 201-205.

\begin{abstract}
Aim: The objectives of this study were to determine the prevalence and associated risk factors of bluetongue virus (BTV) in sheep and bovine ephemeral fever virus (BEFV) in dairy cattle in Jordan.

Materials and Methods: A simple randomized study was designed to collect 600 serum samples from sheep and 300 serum samples from dairy cattle located in the Northwestern parts of Jordan. In addition, data regarding farm management were collected using a pre-tested questionnaire through personal interview to determine potential risk factors. The seroprevalences of BEF and BTVs were determined using serum neutralization test and BTV group-specific competitive enzyme-linked immunosorbent assay, respectively.

Results: The overall seroprevalence of neutralizing antibodies against BEFV in dairy cattle was $45.37 \%$. The overall seroprevalence of BTV group-specific antibodies in sheep was 47.8\% (54\% true seroprevalence). Logistic regression analysis identified geographic location (Irbid) (odds ratio $[\mathrm{OR}]=1.0$; confidence interval $[\mathrm{CI}]=0.5-2.1$ ), no use of disinfectants on the farm $(\mathrm{OR}=1.0 ; \mathrm{CI}=0.05-0.1)$, and lack of veterinary services $(\mathrm{OR}=10 ; \mathrm{CI}=3.5-13.2)$ as risk factors associated with high seropositivity against BTV in sheep. Geographic location (Jarash) $(\mathrm{OR}=3 ; \mathrm{CI}=1.0-5.5)$, age of the animal $(1-2$ years of age $(\mathrm{OR}=1 ; \mathrm{CI}=0.3-1.9)$, and lack of veterinary services $(\mathrm{OR}=9 ; \mathrm{CI}=4-11)$ were identified as risk factors associated with high seroprevalence against BEFV in dairy cattle.
\end{abstract}

Conclusion: Results of this study indicate that BEFV in dairy cattle and BTV in sheep are endemic in Northwestern regions of Jordan. Implementation of appropriate control measures is, therefore, required to reduce the adverse effects of these diseases on animal health and productivity.

Keywords: arthropod-transmitted diseases, biosecurity, control measures, livestock, ruminants.

\section{Introduction}

Arthropod-transmitted viruses in ruminants including the bluetongue virus (BTV) and bovine ephemeral fever virus (BEFV) are important diseases that may result in significant economic losses [1-4]. Arthropod-transmitted viral diseases of livestock animals are associated with severe economic losses due to reduced animal productivity, costs of veterinary services, and restrictions on trade and transboundary transportation of animals and animal products $[5,6]$.

The BTV belongs to the genus Orbivirus of the Reoviridae family. The virus is transmitted by bites of Culicoides midges [7]. Bluetongue disease is considered endemic in many parts of the world including Africa, Asia, and North and South America. Most affected cattle are asymptomatic and act as a

Copyright: Hijazeen, et al. Open Access. This article is distributed under the terms of the Creative Commons Attribution 4.0 International License (http://creativecommons.org/licenses/ by/4.0/), which permits unrestricted use, distribution, and reproduction in any medium, provided you give appropriate credit to the original author(s) and the source, provide a link to the Creative Commons license, and indicate if changes were made. The Creative Commons Public Domain Dedication waiver (http:// creativecommons.org/publicdomain/zero/1.0/) applies to the data made available in this article, unless otherwise stated. natural reservoir of BTV [8]. In sheep, peracute and acute clinical signs of BTV infection are characterized by respiratory dyspnea, swollen tongue, and high morbidity and mortality [9]. BEF is considered a non-contagious viral disease of cattle and water buffalo [1]. It is widely spread in many tropical and subtropical regions in Africa, Asia, Australia, and the Middle East $[10,11]$. The virus belongs to the Ephemerovirus genus of the Rhabdoviridae family. The virus is likely transmitted by bites of mosquitoes and midges $[10,11]$. Clinically, the disease is characterized by high fever, lymphadenopathy, oculonasal discharge, subcutaneous edema, respiratory distress, muscle tremors and stiffness, lameness, and eventually recumbency [12].

Proper understanding of the epidemiology, transmission, and risk factors of arthropod-transmitted diseases is mandatory to develop and implement effective control and prevention measures of these diseases. In Jordan, no reports could be cited in the literature concerning the prevalence of BTV and BEF in livestock populations.

Therefore, the objectives of this study were to determine the prevalence and associated risk factors of BTV in sheep and BEF in dairy cattle. 


\section{Materials and Methods}

\section{Ethical approval and informed consent}

All procedures performed in this study were reviewed and approved by the Institutional Animal Use and Care Committee of Jordan University of Science and Technology. Written and signed consents were obtained from farm owners before the study was conducted.

\section{Study area}

Dairy cattle and sheep production are mainly concentrated in the Northwestern regions of Jordan due to suitable weather and availability of water sources $[13,14]$. Jordan enjoys long moderate to hot and dry summers that extend from mid-April to mid-October while winters are short and cold and extend from December to February [14]. The annual rainfalls in the Northwestern regions of Jordan range from $100 \mathrm{~mm}$ to $700 \mathrm{~mm}$ [14]. Animal production systems are mostly small house holdings to medium-large semi-intensive [13]. Concentrate feed supplement is usually provided most of the year [13].

\section{Selection criteria and sample size}

This study was conducted during the spring and summer of 2012. The targeted municipalities located in Northwestern Jordan were Mafraq, Irbid, Jarash, Ajloun, and Northern part of Jordan Valley. Farms within each municipality were selected using a simple random sampling method. The sample size for each area was calculated according to the equation: $\mathrm{N}=\left(1-\alpha^{1 / \mathrm{D}}\right) \times(\mathrm{N}-[\mathrm{D}-1 / 2])$; where $\alpha$ is $1-$ confidence, $\mathrm{N}$ is the population size, and $\mathrm{D}$ is the expected number of diseased animals in the population [15]. Accordingly, 300 blood samples from dairy cows and 600 blood samples from sheep were collected randomly from selected farms.

\section{Blood samples collection}

Whole blood samples were collected through jugular vein puncture using hypodermic needles and plain Vacutainer tubes. Samples were transferred to the laboratory on ice within 3-4 h after collection. Serum was collected by centrifugation of clotted whole blood samples at $3000 \mathrm{~g}$ for $10 \mathrm{~min}$. Serum was stored at $-80^{\circ} \mathrm{C}$ until analysis was performed.

\section{Serum neutralizing antibodies}

Serum samples from dairy cattle were subjected to serum neutralization test (SNT) to detect antibodies against BEFV according to previously published methods [6]. Briefly, serum samples were inactivated first at $56^{\circ} \mathrm{C}$ for $30 \mathrm{~min}$. Inactivated serum samples were then subjected to a 2-fold dilution (1:4-1:512) in 96-well microplates using minimum essential medium cell culture media supplemented with antibiotics and fetal calf serum (Merck, USA). To perform the serial dilution, $75 \mu$ l of medium were added to first well while the rest of the wells received $50 \mu \mathrm{l}$ of medium. Then to the first well, $25 \mu$ l of sample was added followed by transferring $50 \mu \mathrm{l}$ into the next well. To each well,
$50 \mu \mathrm{l}$ of OIE standard reference BEF strain (TCID $_{50}$; Onderstepoort Veterinary Institute, South Africa) were added and the plates were incubated for $60 \mathrm{~min}$ at $37^{\circ} \mathrm{C}$ and $5 \% \mathrm{CO}_{2}$. After that, $150 \mu \mathrm{l}$ of VERO cells were added to each well and the plates were incubated again for $2-3$ days at $37^{\circ} \mathrm{C}$ and $5 \% \mathrm{CO}_{2}$. The plates were then read by observing the presence of distinctive cytopathic effects (CPEs). The highest serum titer was determined as the concentration at which more than $75 \%$ of CPEs were inhibited.

\section{Complement enzyme-linked immunosorbent assay (CELISA)}

Serum samples from sheep were analyzed using BTV-specific cELISA kits according to the manufacturer's instructions (IDEXX, France). Positive and negative controls were provided by the manufacturer. The microplates were read by measuring the optical density at $450 \mathrm{~nm}$.

\section{Questionnaire}

A pre-tested questionnaire to collect data related to management, health, and production was administered by personal interview of the owners or managers of participating farms. Data collected included geographic location of the farm, type of management system used on the farm, herd size, age of the animals, presence of farm dogs, use of disinfectants on the farm, purchasing of new animals from local markets, availability of regular veterinary services, sources of drinking water, and sources of feedstuff.

\section{Statistical analysis}

Risk factors were evaluated by transforming the collected data into Microsoft Excel sheets. Data were then subjected to initial screening using Chi-square test (univariate). Parameters with significant differences were then subjected to multivariate logistic regression model. Risk factors were considered statistically significant at $\mathrm{p} \leq 0.05$. Statistical analysis was performed using SPSS software version 24 (IBM, NY, USA).

\section{Results}

Seroprevalence of neutralizing antibodies against BEFV in dairy cattle

The overall seroprevalence of neutralizing antibodies against BEFV in dairy cattle in the study area was $45.37 \%$. The seroprevalences according to the geographical location were $56.7 \%$, and $36.9 \%$ in Jarash and Jordan Valley, respectively. No positive samples were detected in Irbid, Mafraq, and Ajloun. The serum titers of neutralizing antibodies ranged from $1: 4$ to $1: 64$.

\section{Seroprevalence of BTV in sheep}

The overall seroprevalence of BTV serogroup-specific antibodies in sheep in the study area was $47.8 \%$. The true seroprevalence was $54 \%$ based on $99.1 \%$ specificity, $84.5 \%$ sensitivity, and $84.5 \%$ of the ELISA test. The individual animal seroprevalence within positive flocks ranged from $25.5 \%$ to 
$70.7 \%$. According to the geographic location of the study region, the seroprevalences were $70.0 \%, 44.7 \%$, $45.1 \%, 56.4 \%$, and $25.5 \%$ in Irbid, Mafraq, Jordan Valley, Ajloun, and Jarash, respectively.

\section{Risk factors}

Results of risk factor analysis for BTV infection in sheep and BEF infection in cattle are presented in Tables-1-3. Logistic regression analysis identified geographic location (Irbid) (odds ratio $[\mathrm{OR}]=1.0$; confidence interval $[\mathrm{CI}]=0.5-2.1)$, no use of disinfectants on the farm $(\mathrm{OR}=1.0 ; \mathrm{CI}=0.05-0.1)$, and lack of veterinary services $(\mathrm{OR}=10 ; \mathrm{CI}=3.5-13.2)$ as risk factors associated with high seropositivity against BTV in sheep. In cattle, logistic regression analysis identified geographic location (Jarash) $(\mathrm{OR}=3 ; \mathrm{CI}=1.0-5.5)$, age of the animal (1-2 years of age $(\mathrm{OR}=1 ; \mathrm{CI}=0.3-1.9)$,

Table-1: Univariate analysis of risk factors associated with high seropositivity of bluetongue virus group-specific antibodies in sheep $(n=600)$.

\begin{tabular}{llc}
\hline Risk factor & Category & Seropositivity, n (\%) \\
\hline Geographic location & Mafraq & $89(44.7)$ \\
& Jordan Valley & $51(43.6)$ \\
& Ajloun & $53(56.3)^{*}$ \\
& Irbid & $70(70.0)$ \\
Age & Jarash & $24(56.4)$ \\
& $1-2$ years & $113(55.7)$ \\
Presence of farm & $3-5$ years & $174(43.8)$ \\
dogs & Yes & $198(49.1)$ \\
Use of disinfectants & Yes & $89(45.2)$ \\
& No & $166(33.1)^{*}$ \\
Purchasing of new & Yes & $121(56.3)$ \\
animals & No & $198(49.5)$ \\
Availability of & Yes & $89(44.5)$ \\
veterinary services & No & $102(28.3)^{*}$ \\
\hline
\end{tabular}

$* \mathrm{p} \leq 0.05$

Table-2: Univariate analysis of risk factors associated with high seropositivity against bovine ephemeral fever virus in dairy cattle $(n=108)$.

\begin{tabular}{llc}
\hline Risk factors & Category & Seropositivity, n (\%) \\
\hline Geographic & Jarash & $25(76.6)^{*}$ \\
location & Jordan Valley & $25(38.5)$ \\
Type of farm & Cattle & $36(40.9)$ \\
& Mixed cattle & $14(70)$ \\
Age & and sheep & \\
& $1-4$ years & $36(75)^{*}$ \\
Herd size & $4>$ years & $14(20)$ \\
& $1-49$ & $24(48)$ \\
Sources of drinking & Municipality & $10(31.3)$ \\
water & Others & $16(61.5)$ \\
Sources of & Readily mixed & $36(43.8)$ \\
feedstuff & Mixing in the & $0(0)$ \\
& farm & $50(49)$ \\
Presence of farm & Yes & $25(58.1)$ \\
dogs & No & $25(38.5)$ \\
Purchasing of new & Yes & $1(6.7)$ \\
animals & No & $49(52.7)$ \\
Availability of & Yes & $11(24.4)$ \\
veterinary services & No & $39(61.9)^{*}$ \\
\hline
\end{tabular}

$* \mathrm{p} \leq 0.05$ and lack of veterinary services $(\mathrm{OR}=9 ; \mathrm{CI}=4-11)$ as risk factors associated with high seroprevalence against BEFV in dairy cattle.

\section{Discussion}

BEF and BTVs are economically important viral diseases that affect a wide range of domestic and wild ruminants throughout the world [16,17]. In this study, the diagnosis of BTV was accomplished using cELISA which is a serogroup-specific assay able to measure BTV antibodies without the cross-reactivity problems of other tests like agar gel immunodiffusion test. Moreover, cELISA is the prescribed test for international trade by the OIE terrestrial manual and is extensively used worldwide [18]. BEF is a rare disease in Jordan, and therefore, SNT was used according to the OIE recommendations which stated that "single SNTpositive serum sample may be suggestive of BEF in areas where this disease does not normally occur" [19].

This is the first study in Jordan that indicated the presence of BEFV in dairy cattle and BTV in sheep. In this study, the seroprevalence of BEFV and BTV was $45.37 \%$ and $47.8 \%$, respectively. These results are in agreement with previously reported data that indicate widespread of BTV in most countries lying in the tropics and subtropics primarily between latitudes $40^{\circ} \mathrm{N}$ and $35^{\circ} \mathrm{NS}$ [17]. In the neighboring countries, the seroprevalence of BTV has been reported around $34 \%$ in Iran [20,21], 54.1\% in Saudi Arabia [22], and $29.5 \%$ in Turkey [23]. Although no clinical signs of BTV infection in sheep were detected during the collection of samples from selected animals, the high seroprevalence of the disease in the targeted population indicates previous exposure, especially no vaccination programs are implemented in this region. This suggests that the vector responsible for BTV transmission is available and reemergence of the disease could arise in the future; therefore, appropriate control and prevention measures such as biosecurity and vaccination programs must be implemented.

Table-3: Multivariate logistic regression analysis of risk factors associated with high seropositivity against bluetongue virus in sheep and bovine ephemeral fever virus in dairy cattle.

\begin{tabular}{|c|c|c|c|}
\hline Risk factors & OR & $\begin{array}{c}95 \% \text { confidence } \\
\text { interval odds } \\
\text { ratio }\end{array}$ & p-value \\
\hline \multicolumn{4}{|l|}{ Bluetongue virus in sheep } \\
\hline $\begin{array}{l}\text { Geographic location } \\
\text { (Irbid) }\end{array}$ & 1.0 & $0.4-0.7$ & 0.05 \\
\hline $\begin{array}{l}\text { No use of disinfectants } \\
\text { on the farm }\end{array}$ & 1.0 & $0.05-0.1$ & 0.05 \\
\hline $\begin{array}{l}\text { Lack of veterinary } \\
\text { services }\end{array}$ & 10.0 & $3.5-13.2$ & 0.001 \\
\hline \multicolumn{4}{|c|}{ Bovine ephemeral fever virus in dairy cattle } \\
\hline $\begin{array}{l}\text { Geographic } \\
\text { location (Jarash) }\end{array}$ & 3 & $1.0-5.5$ & 0.05 \\
\hline $1-2$ years of age & 1.0 & $0.03-0.09$ & 0.05 \\
\hline $\begin{array}{l}\text { Lack of veterinary } \\
\text { services }\end{array}$ & 9.0 & $4-11$ & 0.001 \\
\hline
\end{tabular}


The overall seroprevalence of BEF in dairy cattle in Northwestern region of Jordan was $45.37 \%$. The highest prevalence of BEF (56.7\%) was reported in Jarash municipality. No vaccination program against BEF is in effect in Jordan and the cattle population is highly susceptible to this disease. The widespread of antibodies against BEF in Jordan indicates previous natural exposure to the virus. This virus may be introduced into Jordan from importation of live cattle from endemic countries or incursions of BEFV from adjacent countries as several outbreaks occurred in Israel [24], Saudi Arabia [25], and Egypt [26]. It has been reported that BEFV can be transmitted to new territories through winds and animal transportation [16].

In this study, risk factor analysis identified the geographic location of the farm, not using disinfectants on the farm and lack of regular veterinary services as risk factors for seropositivity of BTV in sheep. Similar observations were reported in other parts of the world, in which the location of the farm affected significantly the seroprevalence of the disease [27]. It has been reported that arthropod-borne diseases are affected by season and geographic location. This could be due to different climates, altitudes, and wind activity which, in turn, affects Culicoides activity in the region [21]. It is obvious that lack of regular use of disinfectants and absence of veterinary services in farms resulted in widespread of BTV. It is obvious that providing professional veterinary care to diseased animals results in improved outcomes and decreases morbidity and mortality rates. Risk factor analysis revealed the geographic location, age of the animal, and lack of regular veterinary services as risk factors of BEF infection in dairy cattle. These results are similar to previously reported findings of arthropod-borne viruses [21,25]. It has been reported that the region, breed, sex, and age have a significant effect on the seroprevalence of BEFV [25]. In general, young cattle (1-2 years of age) are more susceptible to BEF due to low immunity. In addition, there is no vaccination program against BEF in place in Jordan.

\section{Conclusion}

The results of this study indicate that BEFV in dairy cattle and BTV in sheep are endemic in Northwestern regions of Jordan. Implementation of appropriate control measures is, therefore, required to reduce the adverse effects of these diseases on animal health and productivity in Jordan.

\section{Authors' Contributions}

ZSH conceived, conducted the fieldwork, administered the questionnaires, and drafted the manuscript. ZBI conducted the literature search, data interpretation, and edited the manuscript. AMA designed and supervised the study, performed the statistical analysis, and reviewed the manuscript. All authors read and approved the final manuscript.

\section{Acknowledgments}

This research was funded by the Deanship of Research at Jordan University of Science and Technology (Grant \# 01-12-2012).

\section{Competing Interests}

The authors declare that they have no competing interests.

\section{Publisher's Note}

Veterinary World remains neutral with regard to jurisdictional claims in published institutional affiliation.

\section{References}

1. Walker, P.J. and Klement, E. (2015) Epidemiology and control of bovine ephemeral fever. Vet. Res., 46(1): 124.

2. Oluwayelu, D., Adebiyi, A. and Tomori, O. (2018) Endemic and emerging arboviral diseases of livestock in Nigeria: A review. Parasit. Vectors, 11(1): 337.

3. Carvelli, A., Sala, M., Autorino, G.L., Scicluna, M.T., Iacoponi, F., Rombolà, P. and Scaramozzino, P. (2019) A cross-sectional serosurvey in a sheep population in central Italy following a blue tongue epidemic. PLoS One, 14(1): e0208074.

4. Schirtzinger, E.E., Jasperson, D.C., Ostlund, E.N., Johnson, D.J. and Wilson, W.C. (2018) Recent US bluetongue virus serotype 3 isolates found outside of Florida indicate evidence of reassortment with co-circulating endemic serotypes. J. Gen. Virol., 99(2): 157-168.

5. Tonbak, S., Berber, E., Yoruk, M.D., Azkur, A.K., Pestil, Z. and Bulut, H. (2012) A large-scale outbreak of bovine ephemeral fever in Turkey, 2012. J. Vet. Med. Sci., 75(11): 1511-1514.

6. Bakhshesh, M. and Abdollahi, D. (2015) Bovine ephemeral fever in Iran: Diagnosis, isolation and molecular characterization. J. Arthropod Borne Dis., 9(2): 195-203.

7. Ruder, M.G., Lysyk, T.J., Stallknecht, D.E., Foil, L.D., Johnson, D.J., Chase, C.C., Dargatz, D.A. and Gibbs, E.P. (2015) Transmission and epidemiology of bluetongue and epizootic hemorrhagic disease in North America: Current perspectives, research gaps, and future directions. Vector Borne Zoonotic Dis., 15(6): 348-363.

8. Maclachlan, N.J., Mayo, C.E., Daniels, P.W., Savini, G., Zientara, S. and Gibbs, E.P. (2015) Bluetongue. Rev. Sci. Tech., 34(2): 329-340.

9. Dal Pozzo, F., Saegerman, C. and Thiry, E. (2009) Bovine infection with bluetongue virus with special emphasis on European serotype 8. Vet. J., 182(2): 142-151.

10. Trinidad, L., Blasdell, K.R., Joubert, D.A., Davis, S.S., Melville, L., Kirkland, P.D., Coulibaly, F., Holmes, E.C. and Walker, P.J. (2014) Evolution of bovine ephemeral fever virus in the Australian episystem. J. Virol., 88(3): 1525-1535.

11. Alikhan, M., Al Ghamdi, K. and Mahyoub, J.A. (2014) Aedes mosquito species in Western Saudi Arabia. J. Insect Sci., 14(69): 1-7.

12. Radostits, O.M., Gay, C.C., Blood, D.C. and Hinchcliff, K.W. (2007) Veterinary Medicine: A Textbook of the Diseases of Cattle, Sheep, Pigs and Horses. 10 ${ }^{\text {th }}$ ed. Saunders, Elsevier, Philadelphia, PA. p1177-1179.

13. Doomi, M.B (2016) The relationship between precipitation and topography in Northern Jordan using principal component-based GIS analysis. Dirasat Hum. Soc. Sci., 43(1): 275-284.

14. Alqaisi, O., Ndambi, A., Uddin, M.M. and Hemme, T. (2010) Current situation and the development of the dairy industry in Jordan, Saudi Arabia, and Syria. Trop. Anim. 
Health Prod., 42(6): 1063-1071.

15. Fostage, G.T. (2009) Practical sample size calculations for surveillance and diagnostic investigations. J. Vet. Diagn. Invest., 21(1): 3-14.

16. Aziz-Boaron, O. (2012) Circulation of bovine ephemeral fever in the Middle East-strong evidence for transmission by winds and animal transport. Vet. Microbiol., 158(3-4): 300-307.

17. OIE Manual of Diagnostic Tests and Vaccines for Terrestrial Animals. (2019) Available from: https://www.oie.int/standard-setting/terrestrial-manual/access-online. Retrieved on 25-12-2019.

18. Bovine Ephemeral Fever. (2016) Available from: https://www.cfsph.iastate.edu/Factsheets/pdfs/bovine ephemeral_fever.pdf. Retrieved on 15-12-2019.

19. Gibbs, E.P.J. and Greiner, E.C. (1994) The epidemiology of bluetongue. Comp. Immunol. Microbiol. Infect. Dis., 17(3-4): 207-220.

20. Shoorijeh, S.J. and Ramin, A.G. (2010) High seroprevalence of bluetongue virus infection in sheep flocks in West Azerbaijan, Iran. Comp. Immunol. Microbiol. Infect. Dis., 33(3): 243-247.

21. Khezri, M. and Azimi, S.M. (2013) Epidemiological investigation of bluetongue virus antibodies in sheep in Iran. Vet. World, 6(3): 122-125.
22. Yousef, M.R. (2012) High seroprevalence of bluetongue virus antibodies in sheep, goats, cattle and camel in different districts of Saudi Arabia. Vet. World, 5(7): 389-393.

23. Gür, S. (2008) A serologic investigation of bluetongue virus in southeastern Turkey. Trop. Anim. Health Prod., 40(3): 217-221.

24. Yeruham, I., Van Ham, M., Stram, Y., Friedgut, O., Yadin, H., Mumculoglu, K.Y. and Braverman, Y. (2010) Epidemiological investigation of bovine ephemeral fever outbreaks in Israel. Vet. Med. Int., 2010: 290541.

25. Zaghawa, A., Housawi, F.M., Al-Naeem, A., Al-Nakhly, H., Kamr, A. and Toribio, R. (2016) Risk analysis and seroprevalence of bovine ephemeral fever virus in cattle in the Kingdom of Saudi Arabia. Trop. Anim. Health Prod., 48(3): 487-492.

26. Kasem, S., Dawod, A., Khodier, M., Kotb, A., Abouelyazeed, M., Kareem, S.A. and Ibrahim, B. (2014) Isolation and characterization of bovine ephemeral fever virus in Delta provinces, Egypt 2012. Glob. Vet., 13(6): 972-976.

27. Santman-Berends, I.M., Bartels, C.J., van Schaik, G., Stegeman, J.A. and Vellema, P. (2009) The increase in seroprevalence of bluetongue virus (BTV) serotype 8 infections and associated risk factors in Dutch dairy herds, in 2007. Vet. Microbiol., 142(3-4): 268-275. 